\title{
An Examination of Prehistoric Human Remains at the Victoria Regional Wastewater Treatment Plant, Victoria County, Texas
}

Daniel Potter

Lee Spencer

Follow this and additional works at: https://scholarworks.sfasu.edu/ita

Part of the American Material Culture Commons, Archaeological Anthropology Commons, Environmental Studies Commons, Other American Studies Commons, Other Arts and Humanities Commons, Other History of Art, Architecture, and Archaeology Commons, and the United States History Commons

Tell us how this article helped you.

This Article is brought to you for free and open access by the Center for Regional Heritage Research at SFA ScholarWorks. It has been accepted for inclusion in Index of Texas Archaeology: Open Access Gray Literature from the Lone Star State by an authorized editor of SFA ScholarWorks. For more information, please contact cdsscholarworks@sfasu.edu. 


\section{An Examination of Prehistoric Human Remains at the Victoria Regional Wastewater Treatment Plant, Victoria County, Texas}

\section{Creative Commons License}

\section{(c) (1) (8)}

This work is licensed under a Creative Commons Attribution-NonCommercial 4.0 International License 
AN EXAMINATION OF PREHISTORIC HUMAN REMAINS AT THE VICTORIA REGIONAL WASTEWATER TREATMENT PLANT, VICTORIA COUNTY, TEXAS

Daniel Potter and Lee Spencer

Center for Archaeological Research The University of Texas At San Antonio

Archaeological Survey Report, No. 94 
TABLE OF CONTENTS

Page

Introduction. . . . . . . . . . . . . . . . . . . . . . . 1

The Investigations. . . . . . . . . . . . . . . . . . . . . 1

The Burial. . . . . . . . . . . . . . . . . . . . . . 3

Summary and Recommendations . . . . . . . . . . . . . . . . . 4

References Cited. . . . . . . . . . . . . . . . . . 5

\section{LIST OF FIGURES}

Figure Page

1. Burial Site Soil Profile. . . . . . . . . . . . . . 2 
Introduction

On June 9, 1980, archaeologists from the Center for Archaeological Research, The University of Texas at San Antonio, investigated a reported discovery of human bones where construction is underway at the Victoria Regional Wastewater Treatment Plant, Victoria, Texas.

The Center was informed of the discovery by David Welsch of the GuadalupeBlanco River Authority, who requested that an investigation be made by qualified persons to assess the bone material and immediate surroundings for the purpose of determining the potential importance of the cultural resource.

The field investigations were carried out by Daniel Potter, Lee Spencer, and Robert Scott, all of whom have considerable experience with excavation and evaluation of prehistoric human remains. The fieldwork was done under the general supervision of $\mathrm{Dr}$. Thomas R. Hester and Jack D. Eaton.

The Investigations

The general area where the bone material was uncovered has recentiy been disturbed by extensive excavations as part of the wastewater treatment plant construction. The plant is located on the modern Guadalupe River floodplain, approximately 2.5 miles south of Victoria, on the north side of Loop 175. General topography in the area is very flat, and buried depositional zones mirror this condition. The bone was encountered in the soil profile of a relatively small excavation which had been dug to install a concrete junction box, in the approximate center of the plant. Work had been stopped until archaeologists could make an assessment.

Upon examination, the bone was determined to be that of a single human interment and evidently prehistoric in date. Most of the bone material had been removed by workmen before the archaeologists arrived, but enough material was left in place to make some evaluation regarding burial placement and position. The bones already removed by workmen were sufficient in type and preservation to describe age and sex. The human remains will be discussed below. No burial artifacts or other cultural or chronologically diagnostic materials were found with the interment.

Inspection of the soil profile in the immediate area of the burial indicated that there was no intrusive pit associated with the remains; the interment was evidently contemporaneous with soil stratum $E$ shown in the soil profile sketch (Fig. 1). Continued inspection of the area revealed no other human bone, indicating that this was probably an isolated interment.

The soil stratum observed consists of at least seven defined zones. Described in descending order, they consist of the following (see Fig. 1): 


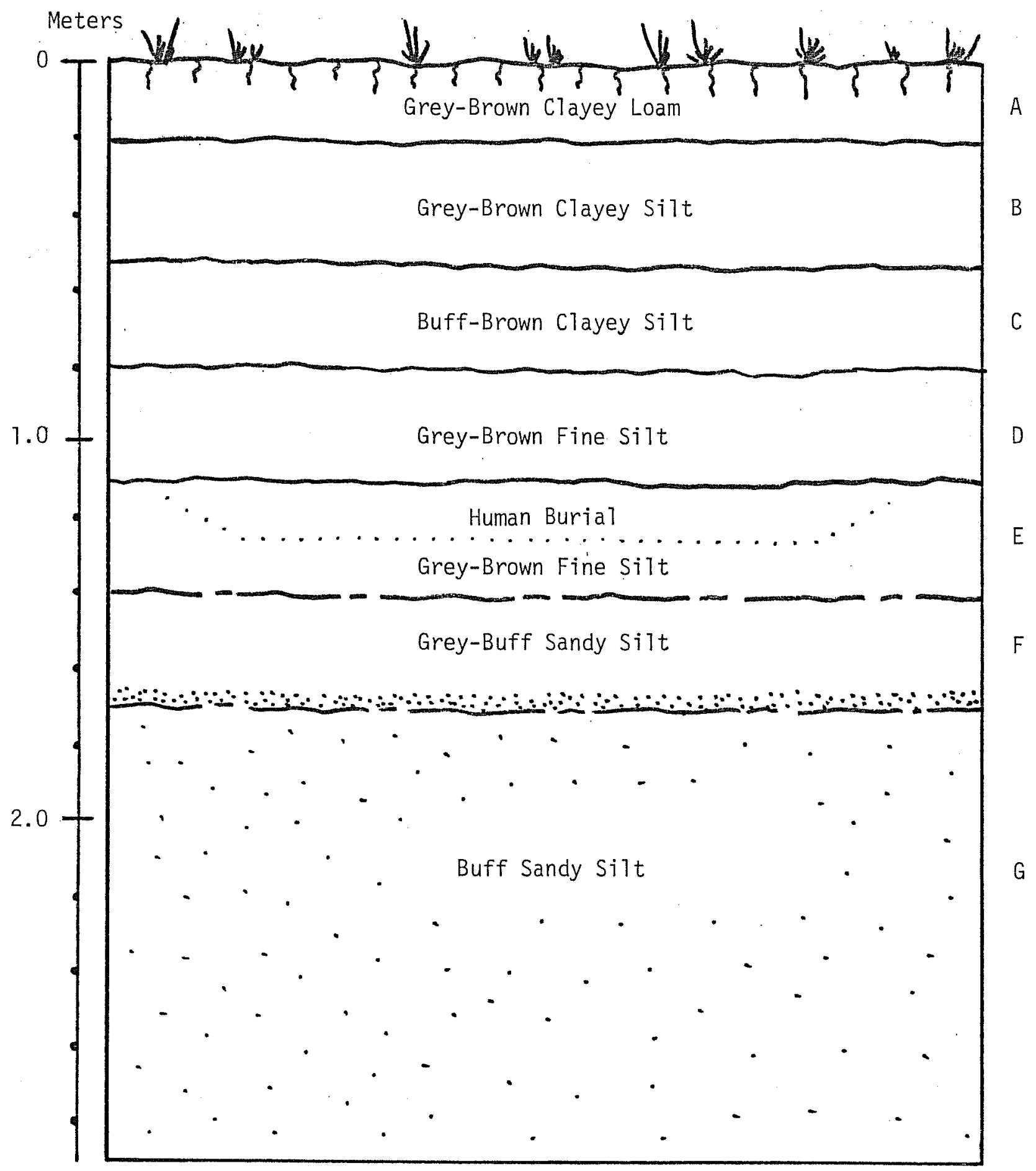

Figure 1. Burial site Soil Profile. 
Zone $A$ is a medium grey-brown compacted clay-loam topsoil with numerous root and insect intrusions. The dry soil is structured into small prismatic peds. A few snail shell fragments were noted.

Zone $B$ is a dark, grey-brown, tight clayey silt, also structured where dry into prismatic peds. Numerous snail shells were noted.

Zone $C$ is a buff to light brown massive clay-silt with an increased amount of sand. Few snail shells were noted.

Zone $D$ is a grey-brown structured fine silt. Numerous snail shells were noted.

Zone $E$ is a light grey-brown unstructured fine silt. The burial was located in the upper half of this zone. Soil zone distinctions below are poorly defined.

Zone $F$ is a light grey-to-buff sandy silt. A slightly darker soil band extends across the base of the zone. Noted in the soil were some snail shells and very small bone particles.

Zone $G$ is a buff massive sandy silt with light grey-green inclusions. Very few snail shells were noted.

The Burial

The Bone Material

When the archaeologists arrived at the project site, about $70 \%$ of the bones had already been removed from their original context. Apparently this removal was accomplished with pry-bars so that most of the bone was in fragmentary condition. The above situation and the juvenile age of the individual was responsible for the fragmentary nature of the bone. This is unfortunate because depositional conditions had preserved the bones quite we11.

Due to time considerations the archaeologists decided to remove most of the deposit overlying the burial with a backhoe (provided by the construction company) to attempt a horizontal exposure of the remaining bones. This worked admirably, and it was possible to expose the undisturbed portions of the skeleton. The remaining bones were some of the lower ribs; the lumbar region of the vertebral column; the pelvis; the proximal ca. $10 \mathrm{~cm}$ of the femurs; and the metatarsals and tarsals, with the ankle bones.

These bones were in articulated position. The positioning of the remnant bones suggests that the body was buried in a flexed position, either on its back with subsequent slumping to the southeast, or originally on its side facing southeast. The top of the head was oriented to the south-southwest.

An examination of the USGS 7.5 minute quadrangle, Victoria West, indicates the original ground surface in the area was probably floodplain alluvial deposits between 44 and 45 feet above sea level. The excavated remnants of the burial were found between 41 feet 4 inches and 40 feet 1 inch above sea level. This 
would indicate that the burial was a minimum of three to four feet below the present ground surface, even considering the simplification involved in the 7.5 minute quadrangle for the area.

No time-diagnostic artifacts or other indicators were found in association with the bones, so its time frame is unknown.

Age, Sex, and Death

After analysis of the skeletal materials, it was determined that the bones were from a teenage boy, ca. 13 to 14 years old.

The age determination was made through observation of the condition of the pubic symphysis, epiphyseal union, and tooth eruption. The epiphyses of some of the ankle bones and toes were fused with their shafts; otherwise only the lateral epicondyle of the humerus was fused. This location fuses between 11 and 17 years of age in males (Ubelaker 1978:53, Table 6). Major bones with non-fused epiphyses were the distal humerus; the proximal and distal ends of the femur, as well as the greater and lesser trochanters of this bone; the proximal tibia; and the iliac crest. Also non-fused were the three bones of the pelvis, the pubis, the ischium, and the ilium. Variously, these data indicate an age younger than 14, 15, or 16 (ibid.). These were the only portions of these bones on which union condition could be discerned.

The condition of the symphysis indicated the individual was younger than 18 years old. The lower right molar was not erupted, and its roots were incompletely formed. According to Ubelaker (1978), this condition suggests an age of $15 \pm 3$ years. Considered together with the above data, an age of 13 to 14 years seems the best average.

Pelvic features indicate the sex of the individual was male. These features were the narrowness of the sciatic notch, the flatness of the sacroiliac articular surface, and the absence of a preauricular sulcus.

No pathological or traumatic condition which could have produced death is evident from the bones. However, the fragmentary condition of the bones may be responsible for the inability to see these features.

Summary and Recommendations

An investigation was made of skeletal material uncovered at the Victoria Wastewater Treatment Plant construction site. Examination of the bone material by archaeologists from the Center for Archaeological Research, The University of Texas at San Antonio, revealed that the bones were the badly disturbed remains of a single, prehistoric human interment, specifically that of a 13- to 14-year old boy. The remains were at a depth of roughly 1.2 meters below the present ground level in an undisturbed soil stratum. No burial artifacts were associated. All bone material was removed for examination, and no further work is required. 
A careful examination of the area failed to reveal any other human bone; therefore, the remains probably represent an isolated interment. However, should more human bone be uncovered by continued excavations at the plant site, an archaeologist should be notified.

\section{REFERENCES CITED}

Ubelaker, D. H.

1978 Human Skeletal Remains: Excavation, Analysis, Interpretation. Aldine, Chicago. 